\title{
Thomas Nelson Page's "No Haid Pawn": The Gothic Horror of the Southern Plantation
}

Carme Manuel Cuenca

Universidat de València

\begin{abstract}
The stories included in In Ole Virginia have been traditionally regarded by critics as the epitome of plantation fiction since they have been read as the recreation of a dead civilization generating mythical qualities. However, "No Haid Pawn," a tale told by a white man, sheds light on a new facet of Thomas Nelson Page as a postwar Virginian and a southern writer, as well as on his views about what slavery really meant for the Old South.
\end{abstract}

In 1887 Thomas Nelson Page published In Ole Virginia, which soon became one of the most important literary pieces of postwar southern literature. The volume was composed of six stories, four of which, "Marse Chan," "Unc' Edinburg's Drowndin," "Meh Lady" and "Ole 'Stracted," had already been published in different northern literary magazines. The other two, "No Haid Pawn" and "Polly," had been written for this collection. The book was immediately acclaimed by critics as the most significant southern contribution to the local color school. They drew attention to the elegiac tone of the majority of the stories and to the magnificence with which the author had painted the fall of the antebellum Old South.

But not all the stories conform to this broad description. In fact, "No Haid Pawn" fails to come up to the expectations of a reader eager to find a thematic uniformity throughout In Ole Virginia. Van Wyck Brooks does not stint his praise of it and emphasizes its originality among Page's fiction: "one of Page's good stories was 'No Haid Pawn,' about the house in the woods by the stagnant pond where an evil man had murdered his slaves and, after being hanged himself, reappeared as a headless phantom in the desolate canebrake. This was a tale one long remembered and its potent atmosphere might have explained the well-known American fondness for stories of ghosts; for what scene was ever more typically American than a rotting old house in a swamp, and what so leads itself to the presence of ghosts?" (46). But, according to Merrill M. Skaggs, it can be considered 
as "an unusually feeble attempt at a Poesque horror tale" (10). Theodore L. Gross deems it likewise and thinks it stands as the only story in the volume which does not stress the historical meaning of the vanished southern past, as it is a simple ghost story shaped in the style of Edgar Allan Poe's terror tales (Thomas Nelson 34). In his article, "Thomas Nelson Page: Creator of a Virginia Classic," devoted exclusively to the study of the stories of In Ole Virginia, Gross underlines the fact that "No Haid Pawn," together with "Polly: A Christmas Recollection," "are worth only brief mention for they do not represent any progress in essentials," and both a good example of Page's inability to broaden the scope of his vision. If "Polly" hardly constitutes "a wholesome study in Southern femininity," "No Haid Pawn" is "merely a well told reminiscence of a boyhood terror, both stories being composed in the main of recollections" (349). Kimball King also believes that this story is less interesting than the other tales in the volume and it shows the influence of Poe and of gothic literature. Page draws his inspiration from the Virginia scenery in a way which he would not often repeat to enhance an atmosphere of mystery and thrill. The description of the decayed mansion brings to mind that of the Usher house and the writer resorts to the theme of the buried alive used by Poe in his tale when he describes how the slave victims of malaria were thrown into the swamp even before dying ("Introduction" XXII). Harry A. Toulmin also refers to this influence and to how Page, following Poe, considered that one of the most important elements in a short story was to build an atmosphere intimately related to the context of the narration at the very beginning. "With an atmosphere akin to that of The Fall of the House of Usher, he leads the reader insensible into the heart of the tale until the complete setting is minutely exposed ... The effect is thorough; the atmosphere is made much of in every direction," writes Toulmin (23). Page had always expressed great admiration towards his Virginian countryman and had emphasized, among his most praiseworthy abilities that of transcending the limits of sectionalism. Thus, in "Authorship in the South Before the War," Page stated that Poe's poems were as southern as Wordsworth's were English, since their beauty was "limited by no boundary, geographical or other" (88-89).

But "No Haid Pawn" is far from merely being a simple ghost story. It is a terror tale which makes use of one of the most disturbing elements in the slavery system of the Old South: the cruelty with which masters could treat their slaves. This happened thanks to the social isolation surrounding the plantation life and to the connivance and impunity provided by the law which turned a blind eye to the white men's behaviour and permitted them to commit any outrage. Associated with slavery, there springs up a wide range of questions related to the consequences of the survival of the system: the admission of the existence of runaway slaves, and the importance of the Underground Railway, as a possibility to achieve freedom. Besides, there was the threatening danger embodied by abolitionists and abolitionism; as well as the acknowledgment, either because of the cruelty wielded by the master or because of the diseases and miseries to which they were exposed, that only blacks were the victims. And in both cases this stood as a symbol for the guilt of the white man. On the other hand, Page goes to great lengths to explain how keeping other human beings in subjection meant a great threat to the social framework of the South. He even admits that the danger of slave uprisings and revolts was always at the back of the white man's mind, in contrast to the kind and patronizing image of racial 
relations provided in the first three stories of the volume: "It was the sudden darkening of a shadow that always hung in the horizon. The slaves were in a large majority, and had they risen, though the final issue could not be doubted, the lives of every white on the plantations must have paid the forfeit" (174). ${ }^{1}$ At the same time, Page recognises that the existence of slavery obliged the South to reject any external interference because the selfpreservation of the antebellum southern society required it so. The author is fully aware of the blatant contradictions in the justification of slavery and of the moral debate between the acceptance or refusal of the rules of that society.

"No Haid Pawn" takes place in Virginia in the 1850 s, that is to say when the revival of the slavery system was in full swing, and it contains a wide range of key elements to build up a gothic atmosphere: a dilapidated mansion in the heart of the swamp, the attraction exerted by lakes and lagoons around the river, the power of the superstition of blacks over whites, and the effectiveness of the oral transmission of those same superstitions. Page drew inspiration for this ghost story from a well-known prewar Virginia legend. The narration deals with a long abandoned plantation placed on the marshy banks of a river: "It was a ghostly place in broad daylight, if the glimmer that stole in through the dense forest that surrounded it when the sun was directly overhead deserved this delusive name. At any other time it was-why, we were afraid even to talk about it! and as to venturing within its gloomy borders, it was currently believed among us that to do so was to bring upon the intruder certain death ... the very name inspired dread, and the place was our terror" (162).

The slaves in the neighbourhood believed that the house was haunted by spirits and ghosts, among which there was one of a decapitated black man who had been offered as a sacrifice during the building of the mansion, as well as those of some slaves ill with malaria who were buried alive in the swamp. The mansion had become the property of a new master and, until that moment, no white people had dared to penetrate into the putrid forests surrounding it. This new master was "one more gloomy, more strange, and more sinister than any who had gone before him-a man whose personal characteristics and habits were unique in that country. He was of gigantic stature and superhuman strength, and possessed appetites and vices in proportion to his size" (168-69). He spoke a patois similar to that spoken by the French creoles of Louisiana, though he came from the West Indies. His brutal character was dominated by the most degraded passions and he was feared by his slaves. His isolated life in No Haid Pawn gave rise to fabulous gossip and it was soon believed that he drank human blood to keep his strength. After a long period of corruption and licentiousness, his wickedness culminated in a callous action: he cut off the head of one of his slaves and had it hanged from a window as an example to the other blacks. The authorities had known about this and had arrested and judged him. He had been found guilty and hanged at the back of the house, in the same place where he had committed his terrible crime. He had been buried alive in one of the underground passages of the mansion where the ghost of the decapitated slave used to prowl about. From then on, nobody ever ventured to go near the plantation again because "it was invested to us, with unparallelled horror; and thus to us, no less than because the dikes had given way and the overflowed flats had turned again to swamp and jungle, it was explicable that No Haid 
Pawn was abandoned, and was now untrodden by any foot but that of its ghostly tenants" (171).

According to Lucinda $\mathrm{H}$. Mackethan, one of the three aspects of the prewar world that Page turned into raw material of his Arcady is the plantation with the southern mansion as its centre. In "Marse Chan" and in "Meh Lady," the mansions are the credentials of the heroes in the narratives, visible signs of the spirit of their inhabitants who created an aristocratic utopia in a world placed in the middle of the wilderness. The maintenance of this utopia represented the preservation of the only national bulwark which stood for nonmaterialistic values and, for this very reason, its loss implied death. Notwithstanding, "No Haid Pawn" is the story which least conforms to the idea that Page develops in his former tales. The name of the plantation is weird and it is the antithesis of Oakland-described in "Social Life in Old Virginia Before the War"-and of the other mansions which crop up in In Ole Virginia. In "No Haid Pawn" Page experimented with a new type of setting and atmosphere. According to Mackethan, here Page wants to illustrate what happens to the ideal of the plantation when unworthy men try to imitate the original, since the mansion is built by a stranger, a southern creole from the deep states whose ancestors were French and Spanish. On the other hand, the author underlines the fact that none of the Virginians from the neighbouring plantations had any dealings with its inhabitants. Likewise thinks Kimball King, for whom the author "makes it clear that the offenders came from the deep South and were not Anglo-Saxons" ("Introduction" XXXII). But the tragic end cannot only be justified in terms of a retaliation of nature as a result of the lack of morals or the desparaging attitude towards local customs sported by the creole. Even if it is true that, as Mackethan observes, "the place reflects its owner and thus the true plantation will symbolize and proclaim the ethical superiority of its inhabitants" (44-45), Page here also admits the existence of the hidden face of the plantation and the outrages that the isolation, favoured by the prewar conditions of life, enclosed.

Once the introduction has been presented, Page starts his ghost story and places it sometime in the 1850 s. The anonymous inhabitants of the surrounding areas were feeling anxious since they had discovered the existence of some emissaries, running the Underground Railway in their own neighbourhood, who were regarded as the devil incarnate: "they had been run off or had disappeared suddenly, but had left behind them some little excitment on the part of the slaves, and a great deal on the part of their masters, and more than the usual number of negroes had run away" (171). The narrator describes how in his youth one day he had decided to go hunting near the plantation and "so one afternoon, without telling any one of my intention, I crossed the mysterious boundery and struck through the swamp for the unknown land" (175). At nightfall a frightening storm breaks out and he has to search for shelter among the ruined walls of the decayed mansion. The intensity of the storm increases and the thunders and flashes of lightening lull him to sleep. Some time later a strange whistling-_"like a distant call or halloo" (183)-wakes him up. The whine sounds closer and closer, and when the young man glances at the canal, he catches sight of a canoe rowed by a man with a bulky bag by his side. Then he hears someone hurling the front door open and "a string of fierce oaths, part English and part Creole French," as well as the thud of a body being dragged along the ground and later dropped with a savage chuckle. This makes the narrator think that this apparition is the 
former owner of the plantation: "I knew that the murderer of No Haid Pawn had left his grave, and that his ghost was coming up that stair" (185). Meanwhile he continues:

For a moment there was not a sound, then the awful silence and blackness were broken by a crash of thunder that seemed to tear the foundations asunder like a mighty earthquake, and the whole house, and the great swamp outside, were filled with a glare of vivid, blinding light. Directly in front me, clutching with his upraised hand a long, keen, glittering knife, on whose blade a ball of fire seemed to play, stood a gigantic figure in the very flame of the lightning, and stretched at his feet lay, ghastly and bloody, a black and headless trunk. I staggered to the door and, tripping, fell postrate over the sill. (185-86)

The story ends with this scene, although the reader is later told in a small appendix that a flash of lightning struck the house and burnt it to its foundations, and all its secrets were engulfed by the river. Jean Rouberol speaks about the evil mansion in the works of Poe, Cable and Faulkner. But his research can easily be extended to Page's. The mansion of this story shares the traits of those which appear in the fiction of the above-mentioned southern writers, since in "No Haid Pawn" the house not only stands as the space in the interior of which a process of violence and corruption takes place, but it itself becomes the victim of this same change towards decomposition and aggressiveness. Likewise, No Haid Pawn will end up being devoured by water and the flames of a purifying fire. As Rouberol states, "elle est tantôt lieu de violence et de mort, tantôt symbole d'une malédiction ancestrale, tantôt enfin cercueil ou tombeau de morts vivants" (268).

The alleged ghost seems to be the spirit of the owner of the plantation who had decapitated a slave and had been in his turn decapitated. But, as Louis D. Rubin Jr. observes, the dead come back to life and the mansion is destroyed following the style of the Usher House. Notwithstanding, Page was writing this story in the 1880 s, when the old ghost stories were not fashionable. Thus he felt obliged to provide "a rational explanation for what had happened in 'No Haid Pawn' and he does so before the story actually begins" (97).

At the time the presence of some abolitionists in the area had been stirring up the inhabitants of the neighbourhood. The number of slaves who had ventured to run away, encouraged by the words of these outsiders, had dramatically increased until the northerners had been discovered and forced to leave. Thus the southerners had recovered nearly all their slaves, except one, a black man from the deep South, who spoke a strange dialect and who had a fierce character and bragged about his voodoo powers. Page uses him to establish a difference with the slaves of Virginia, that is to say, between the rebelliousness of a newly imported slave and the submission of the traditional southern plantation blacks: "He was a type rarely found among our negroes, who, judging from their physiognomy and general characteristics, came principally from the coast of Africa. They are of moderate stature, with dull but amiable faces. This man, however was of immense size, and he possessed the features and expression of a Congo desperado" (172). Only his capacity and skill to carry out certain jobs had made him a valuable piece of property to his master's eyes. But it turned out that he had been the leader in the meetings with the 
abolitionists and had vanished into thin air when they had fled from the area. Thus what had really happened in No Haid Pawn that night was that this runaway slave was coming back to the haunted house because he was living there by himself. Neither did the bulky shape belong to any corpse, but to some stolen pig he had killed to survive. The narrator describes in some previous paragraph how the slave was not superstitious and how "more than one hog that the negroes declared had wandered into the marshes of No Haid Pawn, and had 'cut his thote jes' swinin' aroun' in de ma'sh', had been suspected of finding its way to this man's cabin" (173). Besides, "he was a fine butcher, a good work-hand and a first-class boatman," and for these reasons he had become an essential piece in the plantation (173). The story then reveals some interesting facts about the Old South and slavery, and Page himself seems perfectly aware of the relationship. Hence he writes about the appearance of abolitionists: "It was as if the foundations of the whole social fabric were undermined. It was the sudden darkening of a shadow that always hung in the horizon. The slaves were in a large majority, and had they risen, though the final issue could not be doubted, the lives of every white on the plantations must have paid the forfeit. Whatever the right and wrong of slavery might have been, its existence demanded that no outside interference with it should be tolerated. So much was certain: self-preservation required this" (174).

Page points out that the mansion had been built by the slaves, that one of them "had been caught and decapitated between two of the immense foundation stones," and that it was rumoured that in its underground "solid rock chambers, which had been built for dungeons, and had served for purposes which were none the less awful because they were vague and indefinite" (167). Before the young protagonist comes into the house, he stops under the beam from which the owner had been hanged. It is important to remember that the latter came from the West Indies, where the slave uprisings had destroyed the French planters, and that the runaway black was from the deep South. This is vital because, no matter how paternalistic the institution of slavery could have been in Virginia, in other southern states it had been terribly brutal, without any of the alleviating traits with which Page tried to embellish the system in his native state. The possibility of taking to cruel and savage extremes the relationship that the system established between master and slaves was always implicit in the institution since, no matter how many justifications were discussed, the terrible truth of what slavery was really about was always lurking in the background, and besides there was the constant fear of uprisings and massacres. In "No Haid Pawn" Page clearly goes beyond the border of the idyllic plantation landscape. He intends to write a ghost story and he resorts to those elements which he finds closer at hand. He sketches a completely different picture from the one found in those narrations where blacks cry over the ashes of their lost old southern paradise. In this tale slaves narrate stories about evil spirits, ghosts and loathesome beings prowling around the swamp,and white children live under the shadow of panic projected by the foundations upon which the southern mansion struggles to survive.

It is necessary to ask what the insertion of such a story means in a volume allegedly devoted to the glorification of the prewar southern plantation and aimed at showing the loyalty, humility, generosity and satisfaction felt by the slaves in that system. It is also necessary to look into the reasons which drove Thomas Nelson Page to write a story of 
horror, depravation and guilt and to include in the same volume other stories which have been saddled traditionally with being the epitome of the plantation tradition, as well as the greatest literary tribute to the prewar southern paradise. "No Haid Pawn" is then essential for understanding this southern writer and, together with other tales of In Ole Virginia, it clearly shows his ambiguous stance towards both the myth of the plantation and of the Old South.

As Michael Flusche says, the scarce critical success of this story must have discouraged Page from exploring a new type of fiction (474). But before its publication he had already felt obliged to dodge some obstacles. "No Haid Pawn" is an excellent example of the scrupulous censorship suffered by the fiction published in northern magazines during this period. Kimball King points out that sometimes the changes suggested by the editors were so arbitrary that the logical development of the narration was destroyed, and he proves his point using the revision of this story as an example. The great amount of violence, above all the scene of the decapitation, made E. L. Burlingame write immediately to Page. In a letter dated 8 January 1887 , this editor advises him to modify the gothic tone in the story and to deepen the exotic atmosphere: "it seemed to me that one incident-the severing of the head at the hanging - was unnecessarily repellent without increasing the force of the story" ("Local Color" 126). Page heeded Burlingame's words and enhanced the mysterious and softened the macabre in the story. But this obsession about not hurting the readers' sensitivity would be the reason which led him to water down the symbolism of the narration and make the plot seem so tangled up. Thus the northern literary market, to which Thomas Nelson Page's stories were addressed, preferred him to continue channelling his efforts towards the production of saccharine vapid tales about the South and to leave behind his intentions of exploring new narrative worlds. It is only possible to speculate about what sort of paths the fiction of this Virginian would have taken, if he had been capable of ignoring the advice of his northern editors and friends and had followed the trail he had blazed in this story.

\section{Notes}

1. The quotations from this work refer to the 1969 edition. I quote the page number between brackets in the text.

\section{Works Cited}

Brooks, Van Wyck. The Confident Years: 1885-1915. New York: E. P. Dutton, 1952.

Flusche, Michael. "Thomas Nelson Page: The Quandary of a Literary Gentleman." The Virginia Magazine of History and Biography 84 (October 1976): 464-85.

Gross, Theodore L. "Thomas Nelson Page: Creator of a Virginia Classic." Georgia Review 20 (Fall 1966): 338-51.

Thomas Nelson Page. New York: Twayne Publishers, 1967.

King, Kimball. Introduction. In Ole Virginia, or, Marse Chan and Other Stories. By Thomas Nelson Page. Chapel Hill: U of North Carolina P, 1969. I-XXXVI. 
"Local Color and the American Magazine." Essays Mostly on Periodical Publishing in America: A Collection in Honor of Clarence Gohdes. Ed. James Woodress. Durham: Duke UP, 1973. 121-33.

Mackethan, Lucinda H. The Dream of Arcady: Place and Time in Southern Literature. Baton Rouge: Louisiana State UP, 1980.

Page, Thomas Nelson. "Authorship in the South Before the War." The Old South: Essays Social and Political. New York: Charles Scribner's Sons, 1906. 67-109. 1969.

Rouberol, Jean. L'esprit du Sud dans l'oeuvre de Faulkner. Paris: Didier Érudition, 1975.

Rubin, Louis D., Jr. “The Other Side of Slavery: Thomas Nelson Page's 'No Haid Pawn." 'Studies in the Literary Imagination 7 (Spring 1974): 95-99.

Skaggs, Merrill M. The Folk of Southern Fiction. Athens: U of Georgia P, 1962.

Toulmin, Harry A. Social Historians. Boston: Gorham P, 1911.

\title{
SHAKESPEARE BULLETIN
}

A Journal of Performance Criticism and Scholarship

\author{
Co-Editors \\ James P. Lusardi \\ June Schlueter
}

Now in its twelfth year Published quarterly in 48-page issues Incorporating
Shakespeare on Film Neresletter
Subscription: $\$ 15$ per year

Send your check to Shakespeare Bulletin Lafayette College Easton, PA 18042 (610) $250-5245$.

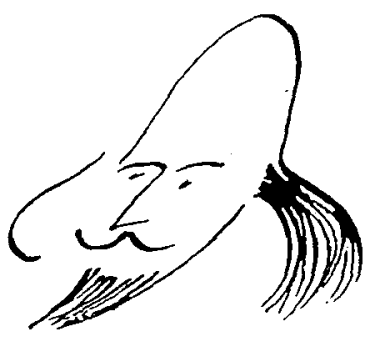

